\title{
Use of Fresh Scotta Whey as an Additive for Alfalfa Silage
}

\author{
Marco Mariotti *(D), Filippo Fratini, Domenico Cerri, Victoria Andreuccetti, Roberta Giglio, \\ Francesco G. S. Angeletti and Barbara Turchi
}

Department of Veterinary Science, University of Pisa, viale delle Piagge 2, 56124 Pisa, Italy; filippo.fratini@unipi.it (F.F.); domenico.cerri@unipi.it (D.C.); victoria.andreuccetti@for.unipi.it (V.A.); robyg90@hotmail.it (R.G.); francesco.angeletti@phd.unipi.it (F.G.S.A.); barbara.turchi@unipi.it (B.T.)

* Correspondence: marco.mariotti@unipi.it; Tel.: +39-050-221-6792

Received: 7 February 2020; Accepted: 4 March 2020; Published: 6 March 2020

check for updates

\begin{abstract}
Scotta is a dairy industry waste obtained by ricotta cheese production. Because of its high availability and its high lactose content, scotta could be used as an additive to improve fermentation characteristics of alfalfa silage. Silage samples were obtained for 2 years from an alfalfa second cut, collecting the forage at three growth stages: mid bud (MB), early flowering (EF), and late flowering (LF). After wilting the forage at $38 \%$ dry matter (DM), four scotta doses were added $(0,75,150$, and $300 \mathrm{~g} / \mathrm{kg}$ fresh forage) and the main chemical and microbiological characteristics were evaluated after 3,13 , and 90 days of ensiling (DOE). The lowest $\mathrm{pH}$ (4.3) was recorded in the EF and LF growth stages, after $90 \mathrm{DOE}$ and with the highest scotta dose ( $300 \mathrm{~g} / \mathrm{kg}$ fresh forage). After $90 \mathrm{DOE}$, the concentration of the main spoilage microorganisms and clostridial spore loads was always negligible. The addition of scotta decreased $\mathrm{pH}$ and fiber fractions, increased the relative feed value, and had no effect on the crude protein concentration or the total digestible nutrients. Therefore, the scotta can be successfully used as an additive to improve the fermentation characteristics of alfalfa silage.
\end{abstract}

Keywords: alfalfa; silage additive; scotta; fermentative bacteria

\section{Introduction}

Legumes are difficult to ensile successfully without an additive, and this is especially true for alfalfa (Medicago sativa L.). McDonald [1] reported that the difficulty of ensiling legumes was attributable to three factors: i) legumes are highly buffered, ii) they tend to have a low water-soluble carbohydrate (WSC) content, and iii) they often have low dry matter (DM) content. As a result, it is difficult to quickly reduce the silage $\mathrm{pH}$, minimize clostridia growth, proteolysis, and heterofermentation, and improve silage palatability. Excessive moisture interferes with the rapid proliferation of lactic acid-producing bacteria, leading to clostridia growth and effluent outflow [2,3]. In fact, it has been recommended that alfalfa should be ensiled with 30-40\% DM [4]. Several works have reviewed the effect of wilting on dry matter losses, silage quality parameters, and animal performance $[3,5,6]$.

The stage of alfalfa maturity at harvest significantly influences the concentration of nutrients, and the right harvesting date is thus very important [7-10]. Lloveras et al. [7] reported that cutting at full bloom stage increased the DM yield compared with cutting at the late bud stage. However, the crude protein $(\mathrm{CP})$ decreases with the advancing of stage of maturity, and the structural carbohydrates increase [10]. Alfalfa shows a low level of WSC, and some authors have found that WSC decreases with advancing maturity $[10,11]$. It is therefore necessary to use some additives to increase the supply of available carbohydrate substrates for the growth of lactic acid bacteria, to inhibit the activity of aerobic bacteria, or to decrease the loss of WSC in the early stage of ensilage [12]. Treatments with alfalfa 
silage additives, such as previously fermented juice $[13,14]$, lactic acid bacteria $[15,16]$, and sucrose [1], may improve the fermentation quality of alfalfa silage.

Ricotta cheese whey, also known as scotta, is a valuable source of the lactose (about 4\% w/w) [17], so it could be used as a silage additive. To date, most of scotta is used as a supplement feed for livestock. In addition, the growing popularity of ricotta cheese in Europe means that the subsequent disposal of increasing amounts of scotta will be a problem. In Italy alone, scotta production amounts to about $0.5 \mathrm{Mt} \mathrm{y}^{-1}[17]$.

The aim of this research was to evaluate whether the scotta whey could be used as an additive to ameliorate the fermentation characteristics of alfalfa silage.

\section{Materials and Methods}

\subsection{Fresh Forage and Silages}

The research was carried out in 2014 and 2015 in a field at the Enrico Avanzi Interdepartmental Centre of Agro-Environmental Research (CIRAA) of the University of Pisa and in the laboratory at the Department of Veterinary Science of the University of Pisa, Italy. The treatments compared in this research consisted of three growth stages at harvest, four scotta doses, and three different opening times of the silages. Three replicates for each treatment were performed. The ensiled forage consisted of second cuts from two 3-year old stands of alfalfa (cv Messe) that were established in adjacent plots in 2012 and 2013. Forage was harvested with a sickle-bar mower at three growth stages: mid bud (MB), stage 3.5 of the Kalu and Fick [18] scale, early flower (EF), stage 5, and late flower (LF), stage 6. The yield obtained at each stage was determined by weighing the forage harvested from $1 \mathrm{~m}^{2}$ in three replicates. The partitioning of DM in the different plant parts was determined immediately after cutting and separating leaves, stems, and inflorescences from 50 randomly selected stems. The remaining forage was wilted in the field for $24 \mathrm{~h}$ to a DM concentration of approximately $40 \%$. Wilted forage was chopped into $2-3 \mathrm{~cm}$ pieces with a laboratory chopper and ensiled in laboratory mini-silos. The mini-silo consisted of $1 \mathrm{~L}$-glass jars, packed at a density of $150 \mathrm{~kg} \mathrm{DM} \mathrm{m}^{-3}$ [19]. Just before ensiling, the scotta was applied at the rates of $0,75,150$, and $300 \mathrm{~g} \mathrm{~kg}^{-1}$ fresh weight. The main scotta chemical parameters were $\mathrm{pH} 6.19$, lactose $4.28 \%$, lipids $0 \%$, crude proteins $0.43 \%$, and solids $5.60 \%$. The jars were opened on 3,13, and 90 days of ensiling (DOE) for chemical and microbiological analyses.

\subsection{Chemical Analyses of the Silages}

The $\mathrm{pH}$ was determined in the aqueous silage extract, using a $\mathrm{pH}$ meter (Eutech instruments pH 510, Thermo Fischer Scientific, Milan, Italy).

Plant parts and forage were oven dried for DM determination at $75^{\circ} \mathrm{C}$ to constant weight. Forages were analyzed to determine crude protein $(\mathrm{CP})$, ash, ether extract (EE), neutral-detergent fiber (NDF), acid-detergent fiber (ADF), and acid-detergent lignin (ADL), according to Martillotti's method [20]. Hemicellulose and cellulose were estimated as the difference between NDF and ADF and between ADF and ADL, respectively. Water-soluble carbohydrates (WSCs) were obtained using the Luff-Schoorl official method [21]. Lactic and monocarboxylic acids (acetic, propionic, and butyric) were determined by HPLC, according to Canale's method [22]. Total digestible nutrients (TDNs) were estimated, as suggested by National Rerearch Council (2001). The relative feed value (RFV) was calculated to estimate fiber quality [23]. The ammonia nitrogen was determined according to the Wall and Gehrke's method [24].

The CP, NDF, and TDN yields per unit area were calculated by multiplying the yield per hectare and the $\mathrm{CP}, \mathrm{NDF}$, and TDN concentrations, respectively.

\subsection{Microbiological Analyses of the Silages}

For the quantitative microbiological analyses, $10 \mathrm{~g}$ of silage were suspended in $90 \mathrm{~mL}$ of sterile saline solution and homogenized; further serial dilutions were performed in sterile tubes. Bacteria 
belonging to Lactobacillus spp. were enumerated on the Man-Rogosa-Sharpe (MRS) agar (Thermo Fisher Scientific, Milan, Italy) after $48 \mathrm{~h}$ at $37^{\circ} \mathrm{C}$ in anaerobioses; Enterobacteriaceae on violet red bile glucose (VRBG) agar (Thermo Fisher Scientific, Milan, Italy) after $24 \mathrm{~h}$ at $37^{\circ} \mathrm{C}$ in aerobiose; clostridia on reinforced clostridial medium (Thermo Fisher Scientific, Milan, Italy) after $48 \mathrm{~h}$ at $37^{\circ} \mathrm{C}$ in anaerobiose; and yeasts and molds on yeast glucose chloramphenicol (YGC) agar (Thermo Fisher Scientific, Milan, Italy) after 5 days at $25^{\circ} \mathrm{C}$ in aerobiose. The detection limit of the analysis was $2 \log$ $\mathrm{CFU} / \mathrm{g}$. For the statistical analyses, all the values under this threshold were set to $1 \log \mathrm{CFU} / \mathrm{g}$. The presence/absence of Listeria monocytogenes in $10 \mathrm{~g}$ of silage was assessed as follows: A pre-enrichment step in Oxoid Novel Enrichment broth Listeria (Thermo Fisher Scientific, Milan, Italy) at $30^{\circ} \mathrm{C}$ for $24 \mathrm{~h}$, and then by subculturing a loopful of broth-culture onto Agar Listeria Ottaviani Agosti, incubated at $37^{\circ} \mathrm{C}$ for $24 \mathrm{~h}$.

\subsection{Statistical Analysis}

The results were subjected to ANOVA. To analyze the effects of stage of harvest on the yield characteristics of the alfalfa second cut, the main effect of year and growth stage at harvest and their interactions were tested. To analyze the effect of wilting on the chemical characteristics of the fresh forage, the main effects of year and wilting and growth stage at harvest and their interactions were tested. To analyze the effect of DOE and the scotta dose on the pH, WSC, lactic acid, volatile fatty acids, and the biological characteristics of the alfalfa silage, the main effects of year and DOE and growth stage at harvest and scotta dose and their interactions were tested. To analyze the effect of the scotta dose on the bromatological characteristics of the alfalfa silage, the main effects of year and growth stage at harvest and scotta dose and their interactions were tested. The combined analyses over years was conducted after verifying the homogeneity of error variance by the chi-square test. Regression analysis was performed to test the relationships between $\mathrm{pH}$ and scotta dose. Correlation analysis was performed to test the relationships between $\mathrm{pH}$, WSC, lactic acid, and protein concentrations. CoStat statistical package vers. 6.451 (CoHort Software, Berkeley, CA, USA) was used, and, in all analyses, the year and treatments were considered as fixed effects. Significantly different means were separated at the 0.05 probability, level by Tukey's (HSD) test.

\section{Results}

Neither the year mean effect nor any of the interactions of year with other treatments were significant for any of the measured or calculated parameters. This was probably because the differences were very low between soil conditions (two adjacent plots) and between years: In the period of October-June, it rained $760 \mathrm{~mm}$ in 2014 and $742 \mathrm{~mm}$ in 2015 [25]. Accordingly, all data are presented as averaged over years.

\subsection{Characteristics of Alfalfa Yield}

The dry matter yield of the second cut of alfalfa increased from the first to the last harvest $(+120 \%)$, reaching about $3.4 \mathrm{t} \mathrm{ha}^{-1}$ (Table 1). This increase was due to the increase in all the parts of the plant, in particular, the stems and inflorescences (data not shown).

Table 1. Forage dry matter, crude protein, neutral-detergent fiber (NDF), and total digestible nutrient (TDN) yield $\left(\mathrm{kg} \mathrm{ha}^{-1}\right)$ of the second cut of alfalfa as affected by growth stages at harvest. Data are the mean of 2 years and three replicates.

\begin{tabular}{ccccc}
\hline Harvest & Forage & Crude Protein & NDF & TDN \\
\hline Mid Bud & $1548 \mathrm{c}$ & $329.6 \mathrm{~b}$ & $538.2 \mathrm{c}$ & $991.8 \mathrm{c}$ \\
Early Flower & $2426 \mathrm{~b}$ & $440.1 \mathrm{ab}$ & $945.4 \mathrm{~b}$ & $1393.7 \mathrm{~b}$ \\
Late Flower & $3374 \mathrm{a}$ & $540.7 \mathrm{a}$ & $1443.7 \mathrm{a}$ & $1993.1 \mathrm{a}$ \\
\hline
\end{tabular}

Within a column, mean values followed by the same letter are not statistically different for $p \leq 0.05$. 
The phenological stage also changed the proportion of dry matter in the plant organs. From the MB to LF stage, the percentage of leaves and stems decreased in relative value by about $27 \%$ and $14 \%$, respectively, while that of the inflorescences increased by about 10 times (Figure 1).
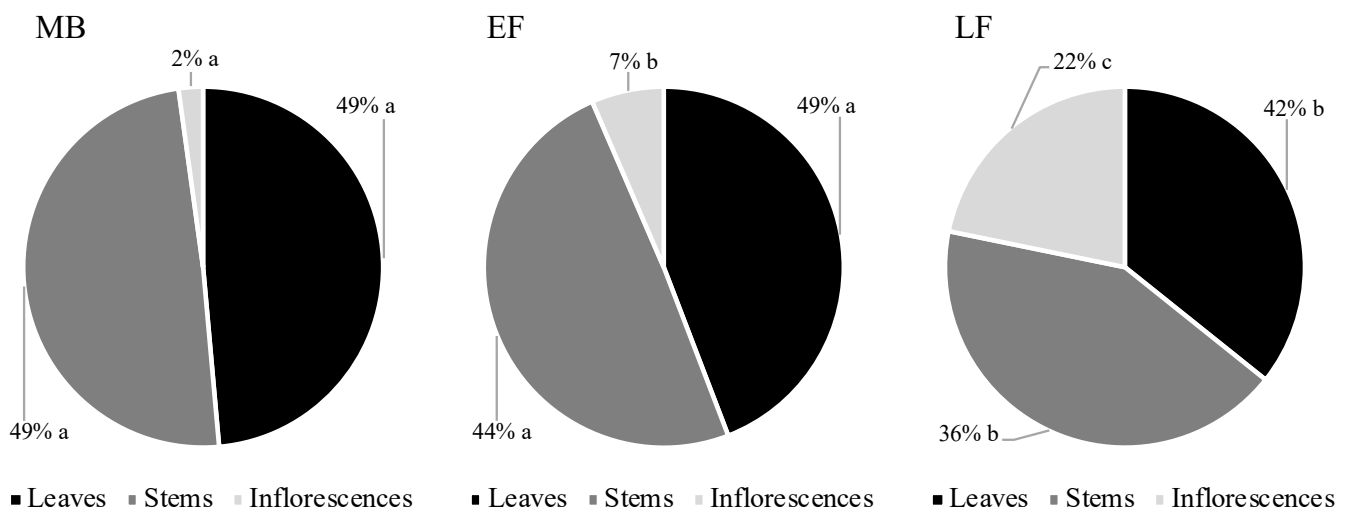

Figure 1. DM partitioning in leaves, stems, and inflorescences, as affected by the growth stage at the harvest mean effect. Mid bud (MB); early flowering (EF); late flowering (LF). Data are the mean of 2 years and three replicates. For each plant part, areas with the same letter are not statistically different for $p \leq 0.05$.

\subsection{Nutritional Characteristics of Alfalfa Forage as Affected by Growth Stage at Harvest and Wilting}

The dry matter concentration in the fresh forage increased from $21 \%$ in $\mathrm{MB}$ to about $27 \%$ in EF and LF stages (data not shown). Wilting increased these values to approximately $38 \%$ at all stages.

No statistically significant interaction was recorded between the growth stage at harvest and wilting for any of the characteristics examined, i.e., wilting similarly affected all characteristics in all three stages.

As a mean effect of the growth stage at harvest, the crude protein, ash, WSC, RFV, and TDN concentrations decreased from the MB to LF stage (Table 2), with the highest decrease recorded for the WSC $(-4 \%$ in relative value). In contrast, the concentration of fiber fractions increased, with the highest increase in the ADL $(+46 \%)$.

Table 2. Crude protein (CP), ether extract (EE), ash, neutral-detergent fiber (NDF), acid-detergent fiber (ADF), acid-detergent lignin (ADL), relative feed value (RFV), total digestible nutrients (TDN), and water-soluble carbohydrates (WSC) of the alfalfa forage prior to ensiling (\% DM), as affected by growth stage at harvest. Data are the mean of 2 years, two wilting treatments, and three replicates.

\begin{tabular}{cccccccccc}
\hline Harvest & CP & EE & Ash & NDF & ADF & ADL & RFV & TDN & WSC \\
\hline MB & $21.3 \mathrm{a}$ & $1.6 \mathrm{a}$ & $8.8 \mathrm{a}$ & $34.7 \mathrm{~b}$ & $24.1 \mathrm{c}$ & $5.6 \mathrm{c}$ & $190.5 \mathrm{a}$ & $64.0 \mathrm{a}$ & $6.3 \mathrm{a}$ \\
$\mathrm{EF}$ & $18.1 \mathrm{~b}$ & $1.7 \mathrm{a}$ & $8.2 \mathrm{~b}$ & $39.1 \mathrm{a}$ & $29.0 \mathrm{~b}$ & $6.8 \mathrm{~b}$ & $160.4 \mathrm{~b}$ & $57.6 \mathrm{~b}$ & $4.1 \mathrm{~b}$ \\
LF & $16.1 \mathrm{c}$ & $1.7 \mathrm{a}$ & $7.4 \mathrm{c}$ & $42.8 \mathrm{a}$ & $31.6 \mathrm{a}$ & $8.2 \mathrm{a}$ & $140.1 \mathrm{c}$ & $59.0 \mathrm{~b}$ & $2.9 \mathrm{c}$ \\
\hline
\end{tabular}

Within a column, mean values followed by the same letter are not statistically different for $p \leq 0.05$.

Although the nutrient concentration decreased from MB to LF, at least for CP and TDN, the yield of CP, NDF, and TDN increased significantly by $64 \%, 168 \%$, and $101 \%$, respectively (Table 1): Therefore, the nutrient yield was a consequence of the greater sensitivity of the biomass accumulation than of the nutrient concentration to the growth stage.

Wilting, averaged over the three stages (Table 3), reduced the EE, NDF, and ADF concentrations, but increased the RFV (+18\%). 
Table 3. Ether extract, NDF, ADF, and RFV of the alfalfa forage prior to ensiling (\% DM). Data are the mean of 2 years, three growth stages at harvest, and three replicates.

\begin{tabular}{ccccc}
\hline Wilting & EE & NDF & ADF & RFV \\
\hline Unwilted & $1.8 \mathrm{a}$ & $41.2 \mathrm{a}$ & $29.4 \mathrm{a}$ & $150.1 \mathrm{~b}$ \\
Wilted & $1.5 \mathrm{~b}$ & $36.4 \mathrm{~b}$ & $27.1 \mathrm{~b}$ & $177.3 \mathrm{a}$ \\
\hline
\end{tabular}

Within a column, the mean values followed by the same letter are not statistically different for $p \leq 0.05$.

\subsection{Fermentation Characteristics of Alfalfa Silage as Affected by DOE and Scotta Dose}

Between the beginning and the end of the ensiling period, the weight of the jars decreased, although in a range of just $0.5-1.0 \%$ (data not shown).

The $\mathrm{pH}$ of the alfalfa silage was affected by the interaction between the DOE, stage of harvest, and scotta dose (Figure 2). Generally, the $\mathrm{pH}$ decreased as the scotta dose increased. This effect was more pronounced as more days elapsed since the ensiling. In addition, the scotta effect on lowering the $\mathrm{pH}$ was slight in the MB and LF stages (approximately $-10 \%)$ and marked in the EF phase $(-17 \%)$. However, using the highest scotta dose, the alfalfa silage $\mathrm{pH}$ reached 4.3 in both the EF and LF growth stages (Figure 2).

The WSC concentration, measured over the ensiling period, showed the highest values in the MB stage and the lowest in the EF and LF stages. In addition, averaged over the harvest and scotta doses, the WSC concentration decreased during the ensiling period, reaching the lowest value at 90 DOE. Finally, averaged over the DOE and stage of harvest, the WSC decreased with the increase in scotta dose (Table 4).

In contrast, the concentration of lactic acid was highest in the EF and LF stages, increasing with the ensiling period and with the scotta dose (Table 4).

The decrease in WSC with the ensiling period and the increase in lactic acid were all linked effects in line with the expected trend of lactic fermentations. In fact, throughout the ensiling period, a strong relationship was found between the WSC and lactic acid concentrations (Figure 3).

In the alfalfa silage, a low amount of $\mathrm{N}-\mathrm{NH}_{3}$ and butyric acid was found, which was not dependent

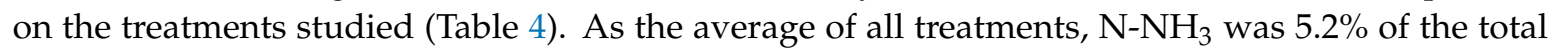
nitrogen and butyric acid was $0.1 \%$. In contrast, propionic acid was always lower than $0.01 \%$.

Minor amounts of ethanol were also detected (at most $0.01 \%$ ) which, among the treatments tested, were found to be exclusively dependent on the DOE (Table 4).

The lactic/acetic ratio was enhanced with the growth stage, the DOE, and the scotta dose, respectively, by $75 \%, 94 \%$, and $58 \%$ in relative value (Table 4 ).

Table 4. WSC, lactic acid, acetic acid, butyric acid, propionic acid, ethanol, $\mathrm{N}-\mathrm{NH}_{3}$ ( $\%$ of total $\mathrm{N}$ ), and lactic/acetic ratio (\% DM) of the alfalfa silage as affected by the mean effects of growth stage at harvest, days of ensiling (DOE), and scotta dose. Values are the mean of 2 years and three replicates.

\begin{tabular}{|c|c|c|c|c|c|c|c|c|}
\hline Treatment & WSC & Lactic Acid & Acetic Acid & Butyric Acid & Propionic Acid & Ethanol & $\mathrm{NH}_{3}$ & Lactic/Acetic \\
\hline \multicolumn{9}{|c|}{ Harvest } \\
\hline MB & $2.61 \mathrm{a}$ & $0.54 \mathrm{~b}$ & $0.27 \mathrm{c}$ & $0.11 \mathrm{a}$ & $<0.01$ & $0.008 \mathrm{a}$ & $4.9 \mathrm{a}$ & $2.0 \mathrm{c}$ \\
\hline EF & $1.09 \mathrm{~b}$ & $1.56 \mathrm{a}$ & $0.57 \mathrm{a}$ & $0.11 \mathrm{a}$ & $<0.01$ & $0.011 \mathrm{a}$ & $5.5 \mathrm{a}$ & $2.7 \mathrm{~b}$ \\
\hline LF & $1.36 \mathrm{~b}$ & $1.62 \mathrm{a}$ & $0.47 \mathrm{~b}$ & $\begin{array}{l}0.13 \mathrm{a} \\
D O E\end{array}$ & $<0.01$ & 0.007 a & $5.3 \mathrm{a}$ & $3.5 \mathrm{a}$ \\
\hline 3 & $2.60 \mathrm{a}$ & $0.47 \mathrm{c}$ & $0.30 \mathrm{c}$ & $0.10 \mathrm{a}$ & $<0.01$ & $0.007 \mathrm{~b}$ & $5.4 \mathrm{a}$ & $1.6 \mathrm{~b}$ \\
\hline 13 & $1.58 \mathrm{~b}$ & $1.47 \mathrm{~b}$ & $0.43 \mathrm{~b}$ & $0.13 \mathrm{a}$ & $<0.01$ & $0.005 \mathrm{~b}$ & $5.6 \mathrm{a}$ & $3.4 \mathrm{a}$ \\
\hline \multicolumn{9}{|c|}{ Scotta $\left(\mathrm{g} \mathrm{kg}^{-1}\right.$ Fresh Weight $)$} \\
\hline 0 & $2.00 \mathrm{a}$ & $0.94 \mathrm{c}$ & $0.40 \mathrm{a}$ & $0.11 \mathrm{a}$ & $<0.01$ & 0.007 a & $5.4 \mathrm{a}$ & $2.4 \mathrm{c}$ \\
\hline 75 & $1.69 \mathrm{~b}$ & $1.05 \mathrm{bc}$ & $0.46 \mathrm{a}$ & $0.12 \mathrm{a}$ & $<0.01$ & 0.006 a & $5.2 \mathrm{a}$ & $2.3 c$ \\
\hline 150 & $1.74 \mathrm{~b}$ & $1.19 \mathrm{~b}$ & $0.42 \mathrm{a}$ & $0.12 \mathrm{a}$ & $<0.01$ & $0.013 \mathrm{a}$ & $5.1 \mathrm{a}$ & $2.8 \mathrm{~b}$ \\
\hline 300 & $1.33 \mathrm{c}$ & $1.77 \mathrm{a}$ & $0.47 \mathrm{a}$ & $0.13 \mathrm{a}$ & $<0.01$ & 0.008 a & $5.3 \mathrm{a}$ & $3.8 \mathrm{a}$ \\
\hline
\end{tabular}

Within a column, the mean values followed by the same letter are not statistically different for $p \leq 0.05$. 


\section{DOE}

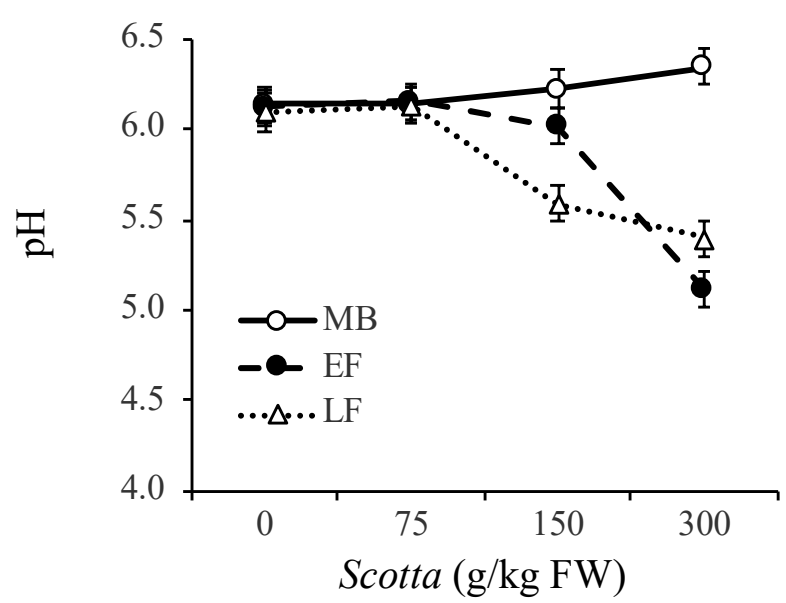

13 DOE

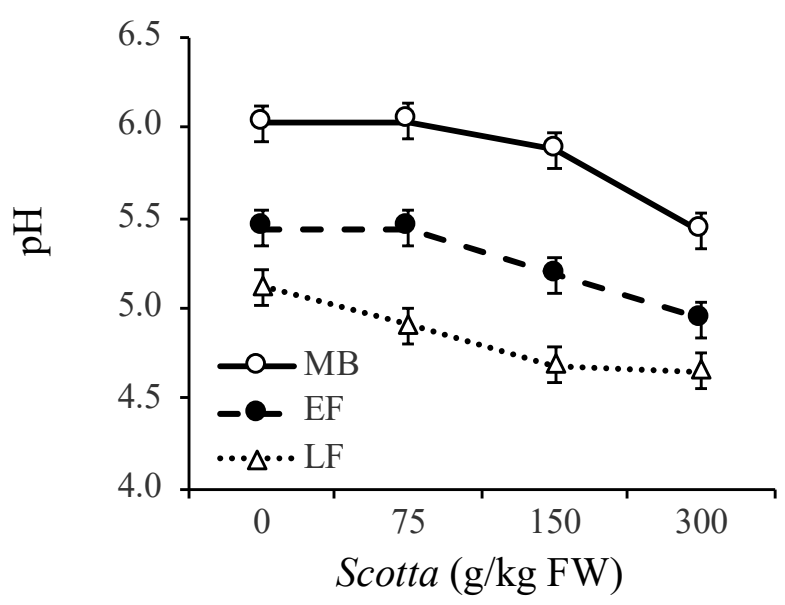

90 DOE

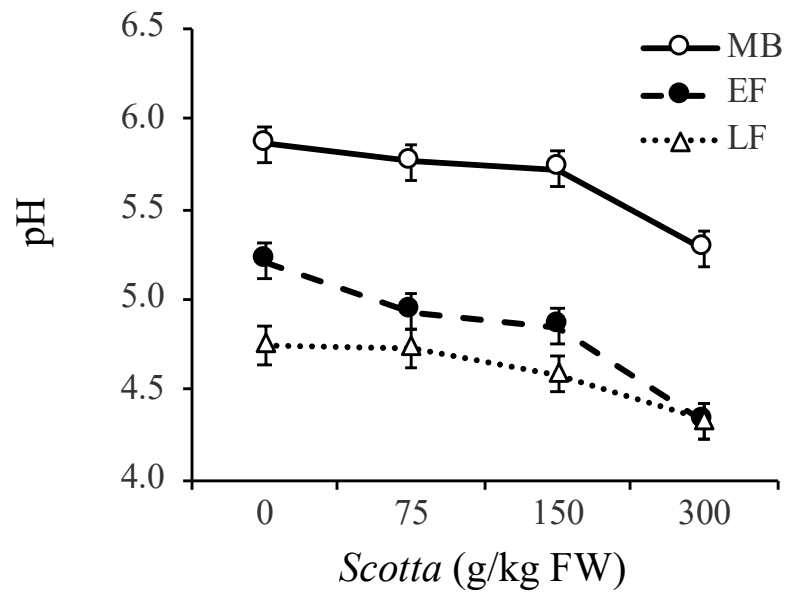

Figure 2. $\mathrm{pH}$ of the alfalfa silage as affected by days of ensiling (DOE), growth stage at harvest, and scotta dose. Vertical bars represent Least Significant Difference at $p \leq 0.05$. 


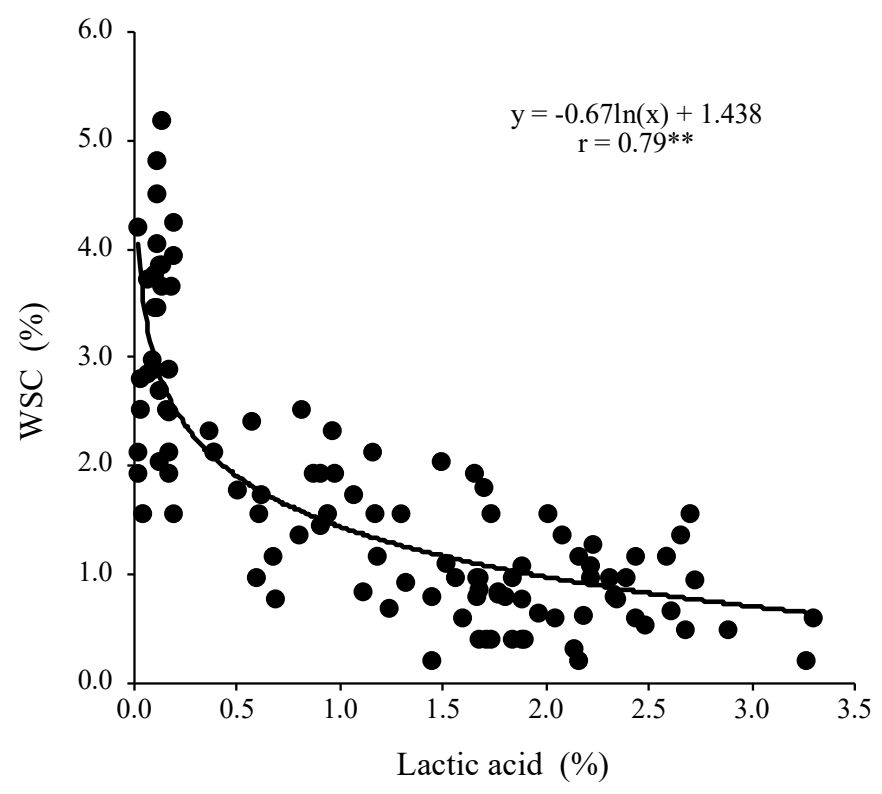

Figure 3. Relationship between WSC and lactic acid throughout the ensiling period and in all harvest stages. Each point represents a mean of 2 years $(n=108){ }^{* *}=p \leq 0.01$.

Before ensiling, the epiphytic bacterial concentrations showed different profiles: MB samples presented the highest bacterial loads, with 6.25, 5.61, 3.79, and $5.65 \log$ (Colony Forming Unit/g) for mesophilic lactobacilli, Enterobacteriaceae, Clostridium spp., and molds, respectively. Compared to MB, the EF and LF samples had lower bacterial concentrations by about $39 \%, 5 \%, 74 \$$, and $12 \%$. Concerning clostridia, spores were not detectable in the EF and LF growth stages. Moreover, forages were all negative for $L$. monocytogenes and yeasts.

In silages, the dynamics of the targeted bacteria and molds were significantly affected by the interaction of the growth stage at harvest and the DOE (Figure 4). In general, the loads showed the highest value after $3 \mathrm{DOE}$ and gradually decreased to the lowest value recorded after $90 \mathrm{DOE}$. At this point, only the Lactobacillus spp. counts were above the detection limit, with values higher than $5 \log$ $\mathrm{CFU} / \mathrm{g}$, except for no detection of the LF samples.

The scotta dose, as the mean of years, growth stage at harvest, and DOE, had different effects on the different microorganisms (Figure 4): A slight reduction in enterobacteria and molds ( -0.29 and $-0.34 \log \mathrm{CFU} / \mathrm{g}$, respectively), a slight increase in Clostridium spp. (+0.43 log CFU/g), and no significant effect on Lactobacillus spp. 
Growth stage at harvest $x$ DOE interaction
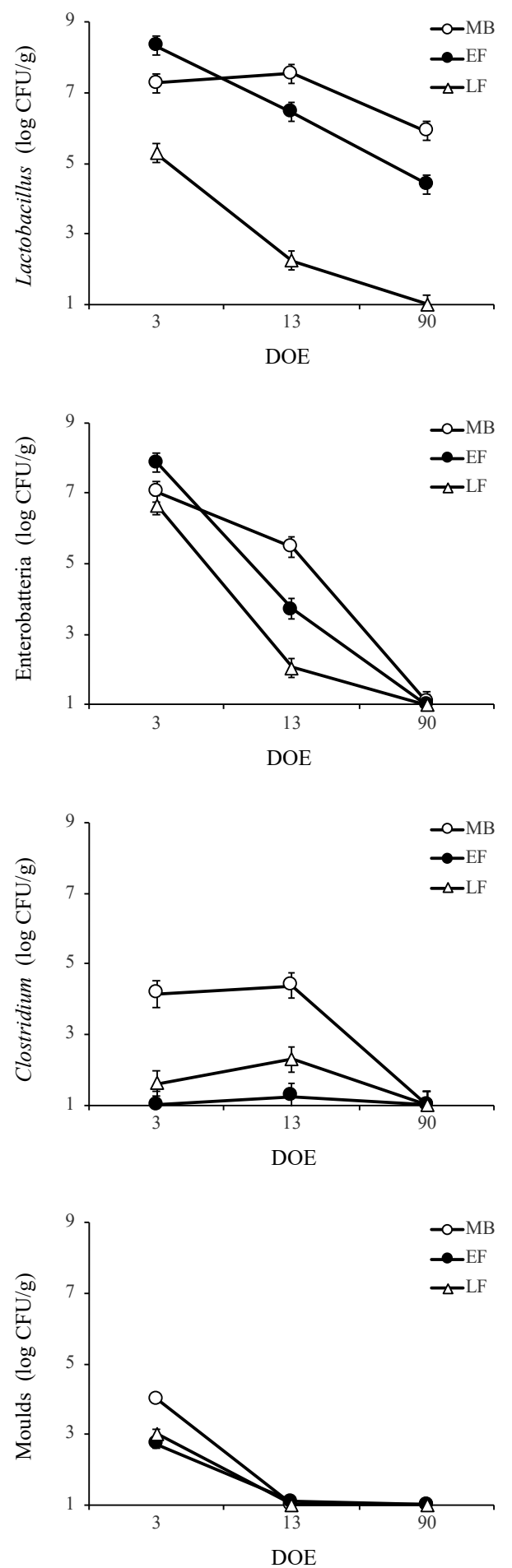

Scotta dose mean effect
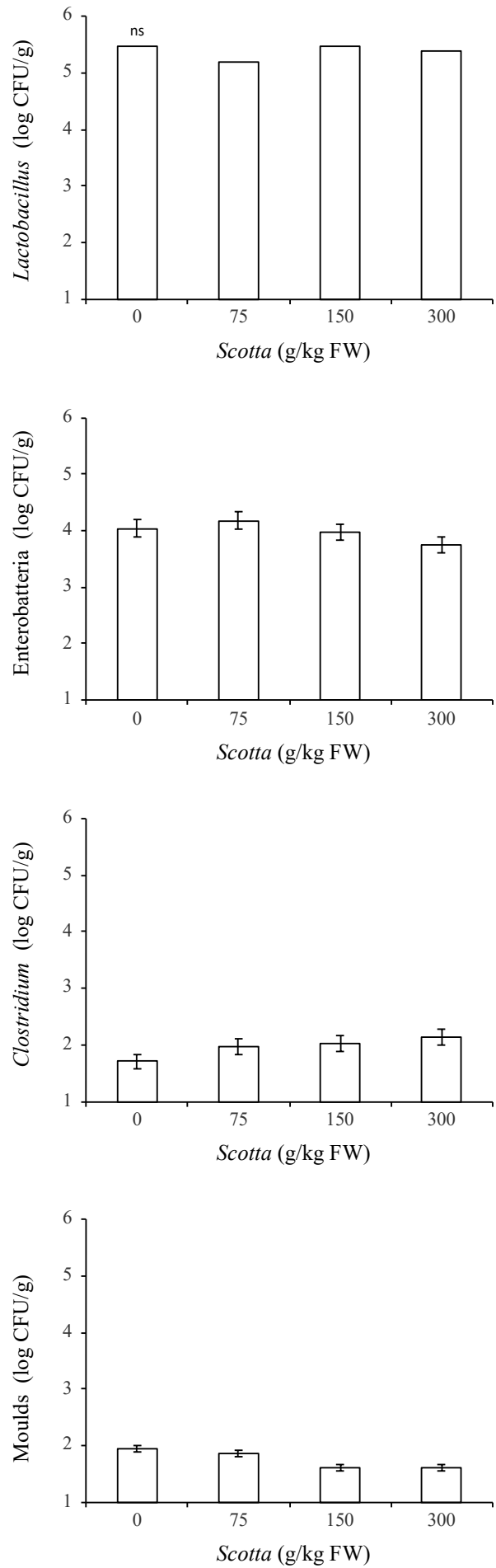

Figure 4. Mesophilic Lactobacillus spp., Enterobacteria, Clostridium spp., and molds, as affected by growth stage at harvest $\times$ DOE interaction (left) and by scotta dose mean effect (right). Vertical bars represent LSD at $p \leq 0.05$ : When not indicated, error bar lies within the symbol. Not significant (NS).

\subsection{Nutritional characteristics of Alfalfa Silage as Affected by Scotta Dose}

After $90 \mathrm{DOE}$, the variations recorded in the nutritional characteristics of the forage were similar to those already observed in fresh forage. Thus, from MB to LF, crude protein, ash, RFV, and TDN decreased, while EE, NDF, ADF, and ADL increased (Table 5). 
Table 5. Crude protein, ether extract, ash, NDF, ADF, ADL, RFV, and TDN after 90 DOE of ensiling $(\% \mathrm{DM})$, as affected by the mean effect of the growth stage at harvest. Data are the mean of 2 years, four scotta doses, and three replicates.

\begin{tabular}{ccccccccc}
\hline Harvest & CP & EE & Ash & NDF & ADF & ADL & RFV & TDN \\
\hline MB & $20.8 \mathrm{a}$ & $1.5 \mathrm{~b}$ & $9.3 \mathrm{a}$ & $30.1 \mathrm{~b}$ & $24.3 \mathrm{~b}$ & $5.3 \mathrm{c}$ & $216.9 \mathrm{a}$ & $64.4 \mathrm{a}$ \\
EF & $17.4 \mathrm{~b}$ & $2.1 \mathrm{a}$ & $8.7 \mathrm{~b}$ & $36.8 \mathrm{a}$ & $30.5 \mathrm{a}$ & $6.6 \mathrm{~b}$ & $165.6 \mathrm{~b}$ & $61.8 \mathrm{~b}$ \\
LF & $16.7 \mathrm{c}$ & $1.9 \mathrm{a}$ & $8.2 \mathrm{c}$ & $39.1 \mathrm{a}$ & $31.6 \mathrm{a}$ & $7.4 \mathrm{a}$ & $155.5 \mathrm{~b}$ & $60.4 \mathrm{c}$ \\
\hline
\end{tabular}

Within a column, the mean values followed by the same letter are not statistically different for $p \leq 0.05$.

The scotta reduced the DM concentration of the forage, which did not drop below 30\% (Table 6). The scotta also increased the ash and RFV, while it decreased the NDF, the ADF, and the ADL with slight variations $(<10 \%$ in relative value).

Table 6. DM concentration, $\mathrm{CP}$, ash, NDF, ADF, ADL, RFV, and TDN of the alfalfa forage after 90 DOE $(\% \mathrm{DM})$, as affected by the mean effect of the scotta dose $\left(\mathrm{g} \mathrm{kg}^{-1} \mathrm{FW}\right)$. Data are the mean of 2 years, three growth stages at harvest, and three replicates.

\begin{tabular}{ccccccccc}
\hline Scotta & DM & CP & Ash & NDF & ADF & ADL & RFV & TDN \\
\hline 0 & $37.0 \mathrm{a}$ & $18.5 \mathrm{a}$ & $8.5 \mathrm{c}$ & $37.0 \mathrm{a}$ & $30.3 \mathrm{a}$ & $6.8 \mathrm{a}$ & $167.9 \mathrm{~b}$ & $61.5 \mathrm{a}$ \\
75 & $34.6 \mathrm{~b}$ & $18.7 \mathrm{a}$ & $8.7 \mathrm{~b}$ & $35.1 \mathrm{~b}$ & $29.5 \mathrm{a}$ & $6.7 \mathrm{a}$ & $178.1 \mathrm{ab}$ & $62.3 \mathrm{a}$ \\
150 & $33.1 \mathrm{c}$ & $18.3 \mathrm{a}$ & $8.9 \mathrm{a}$ & $34.5 \mathrm{~b}$ & $27.9 \mathrm{~b}$ & $6.1 \mathrm{~b}$ & $183.2 \mathrm{a}$ & $62.6 \mathrm{a}$ \\
300 & $29.6 \mathrm{~d}$ & $17.7 \mathrm{a}$ & $9.0 \mathrm{a}$ & $34.6 \mathrm{~b}$ & $27.5 \mathrm{~b}$ & $6.2 \mathrm{~b}$ & $188.1 \mathrm{a}$ & $62.6 \mathrm{a}$ \\
\hline
\end{tabular}

Within a column, the mean values followed by the same letter are not statistically different for $p \leq 0.05$.

A negative linear regression was recorded between the scotta dose and the $\mathrm{pH}$ detected after 90 DOE: As the dose increased, the $\mathrm{pH}$ decreased linearly with different regression coefficients, depending on the growth stage. When the scotta was increased by $100 \mathrm{~g} \mathrm{~kg}^{-1} \mathrm{FW}$, the $\mathrm{pH}$ decreased by 0.19 units in MB, 0.29 units in EF, and 0.15 units in LF (Figure 5).

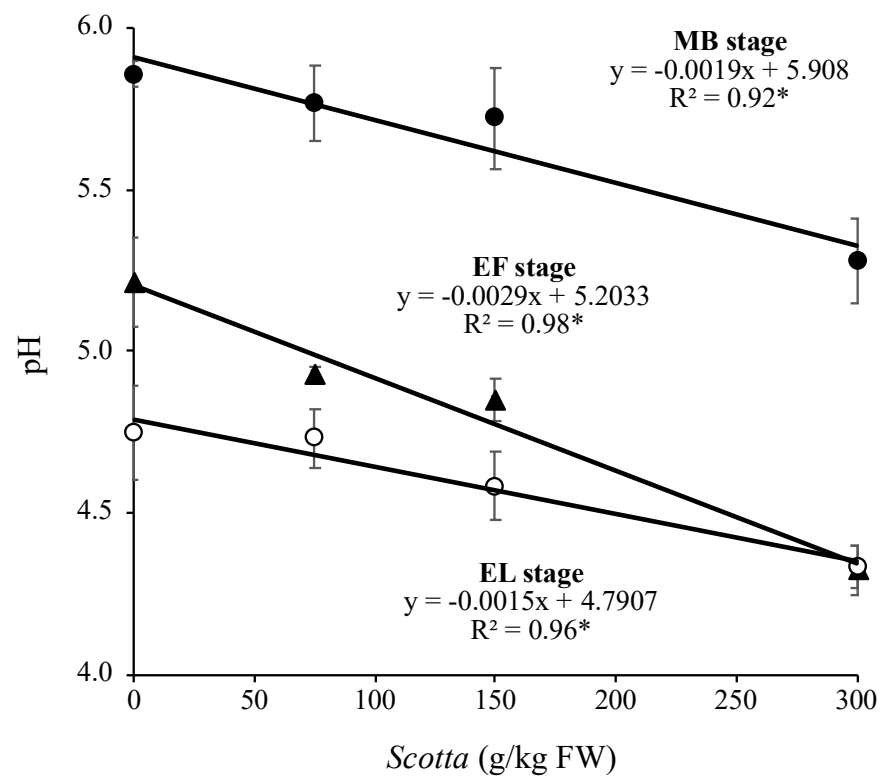

Figure 5. Relationship between $\mathrm{pH}$ at $90 \mathrm{DOE}$ and scotta dose in MB, EF, and LF stages of harvest. Each point represents a mean of three replications and 2 years. Vertical lines represent SD of the mean. $*=p \leq 0.05$.

Considering the data collected at $90 \mathrm{DOE}$, regardless of the growth stage, the $\mathrm{pH}$ of the alfalfa silage correlated positively with the concentration of crude proteins and correlated negatively with the 
concentration of lactic acid (Figure 6). When crude protein and lactic acid increased by one percentage point, the $\mathrm{pH}$ increased by 0.3 or decreased by 0.7 units, respectively.

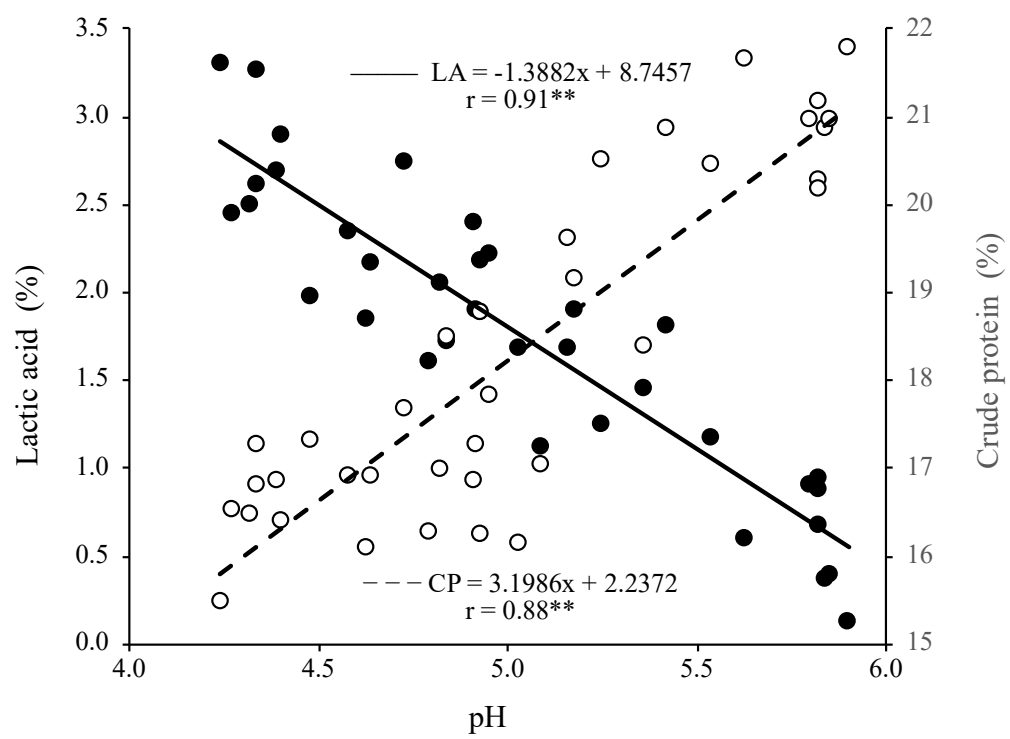

Figure 6. Relationship between $\mathrm{pH}$ at $90 \mathrm{DOE}$, lactic acid $(\mathrm{LA}, \bullet)$ and crude protein concentration $(\mathrm{CP}, \bigcirc)$. Each point represents a mean of 2 years $(n=36) .{ }^{* *}=p \leq 0.01$.

\section{Discussion}

Our study was carried out on a second cut of a 3-year-old alfalfa meadow. The second cut was chosen because, in the cultivation environment, it shows fewer weeds and has the best quality [26]. The alfalfa yield of DM and nutrients increased from MB to LF, and the plants were proportionally richer in inflorescences and poorer in stems and leaves. This led to a decrease in protein concentration, WSC, RFV, and TDN and an increase in various fiber fractions, as also reported by other authors [27-30].

Before ensiling, the forage was subjected to wilting (up to $38 \%$ of DM), a treatment normally used to obtain a forage that does not cause effluents [31]. This treatment had limited consequences on the nutritional characteristics of the forage, with a slight reduction in some fiber fractions (hemicellulose and cellulose) and a slight increase in the RFV.

The $\mathrm{pH}$ of the alfalfa silage decreased as the ensiling progressed and was on average higher in the MB stage than in EF and in LF, i.e., the buffer capacity, which, in our study, was not measured, was probably the lowest in the $\mathrm{EF}$ and highest in the $\mathrm{MB}$ growth stages. In all growth stages, the addition of the scotta decreased the $\mathrm{pH}$, which reached 5.27 in MB and 4.32 in EF and LF. The latter values were lower than those achieved by adding alfalfa forage with fresh whey ( $\mathrm{pH} 4$.67) [32], sucrose (4.58) [33], formic acid (4.36) [34], a chemical additive consisting of formic acid, propionic acid, formate ammonium, and benzoic acid (4.38), a bacterial inoculum (homofermentative and heterofermentative lactic bacteria) (4.47) [15], or a previously fermented alfalfa juice (4.53) [13].

Considering that, with the addition of the scotta, the DM concentration dropped from $38 \%$ to about $30 \%$, the presence of effluents was prevented [1] and the forage was anaerobically stable, but only in the EF and LF phases and not in MB [35].

To the best of our knowledge, this research represents the first investigation evaluating the microbiological profile of experimental silage with added scotta.

Firstly, it is important to highlight the good microbiological quality achieved. Despite the amounts of scotta added, all the samples at 90 DOE showed a remarkable decrease in the main spoilage microorganisms, such as Enterobacteriaceae, molds, and clostridia. The latter are those responsible for the main problems in dairy production; however, at $90 \mathrm{DOE}$, the silages always presented values under the detection limit ( $<2 \log$ spores/g) and thus can be considered of high quality [36]. As for the mesophilic lactobacilli, which are responsible for the desired fermentation, the addition of lactose from scotta did 
not positively or negatively affect the concentration of cultivable microorganisms. It is possible that the microorganisms may have been less efficient in metabolizing lactose, compared to other carbon sources, such as arabinose, glucose, fructose, and xylose, which are typical of plant materials [37]. However, the increase in lactic acid in the silages suggested an active lactose metabolism. Probably, the good microbiological quality was also responsible for the low ammonia nitrogen concentration (about $5 \%$ of the total nitrogen), which was much lower than the maximum (about $12 \%$ ) indicated for legume silages [38].

Secondly, the obtained data suggested that the floral stage played an important role in the microbial dynamics in the silage. In fact, the MB samples presented the highest microbial loads after 13 DOE for Lactobacillus spp., Clostridium spp., and Enterobacteriaceae. This was probably due to a shorter period of exposure to solar radiation, compared to the EF and LF samples, which could have affected the cultivability of the microorganisms [39].

The WSC concentration of alfalfa was different between the growth stages, as reported by Yari [10], and was higher in the MB stage than in EF and LF. In any case, the WSC decreased as the ensiling progressed, during which they were transformed into lactic acid, and consequently the $\mathrm{pH}$ decreased. However, the WSC concentration alone does not guarantee the success in ensiling the alfalfa. In the MB growth stage, the WSC concentration was the highest; however, the $\mathrm{pH}$ did not decrease much. Instead, the silage $\mathrm{pH}$ correlated strongly with the protein concentration, and the protein concentration was particularly high in the MB. Thus, the lowering of the $\mathrm{pH}$ may have been more hampered by the protein concentration, probably by increasing the silage buffer power [1], than favored by the WSC.

The addition of the scotta linearly lowered the silage $\mathrm{pH}$ in all harvest stages, reaching almost optimal values only in the EF and LF growth stages. The equations derived from the regression analysis can be used to estimate that to reach $\mathrm{pH} 4.2$, which is considered as the target for the alfalfa silage conservation [40], about $350 \mathrm{~g}$ of scotta would be needed in the first growth stage and about $400 \mathrm{~g}$ in the second. Considering the EF growth stage, i.e., the stage at which a high quality forage was obtained, the addition of the scotta to reach pH 4.2 would lead to a decrease in DM concentration to $28 \%$, while in the LF growth stage, i.e., the stage in which the high yield of nutrients was reached, the DM concentration dropped to $27 \%$. In both cases, the forages would be in the stable silage area, with regard to the possible proliferation of clostridia, but there would be a low risk of effluent [41]. Wilting, which in our research led to about $38 \% \mathrm{DM}$, should therefore reach about $40 \%$ to prevent effluents.

The main changes in the nutritional characteristics of the forage from the beginning to the end of the ensiling were a slight reduction in crude proteins ( $<5 \%$ in relative value), an increase in the ether extract, a reduction in NDF and ADL (maximum 13\% in relative value), a reduction in hemicelluloses (in 33-46\%), and a slight increase in RFV (approximately $+10 \%$ ) and in TDN (approximately $+3 \%$ ). These variations were very similar to those obtained in other research on alfalfa ensiling carried out with different additives [42-44].

The ratio of lactic acid to acetic acid is used as a qualitative indicator of fermentation and is usually a good quality silage fermentation presents a ratio of about 2.5 to 3.0 [38]. With values higher than 3.0, silage can be aerobically unstable, while values lower than 2.5 can result in poor fermentation. In our research, the values were almost optimal in the EF and LF growth stages, although with the higher scotta dose, aerobic stability may be reduced.

\section{Conclusions}

Our results indicated that the addition of scotta whey as an additive to alfalfa silage had positive effects, which were highlighted by a decrease in $\mathrm{pH}$, a slight reduction in the fiber fractions, and an increase in the relative feed value, while it had no effect on the crude protein concentration and on the total digestible nutrients. The microbiological profile was almost optimal, while the acidic profile seemed to indicate a low aerobic stability of the silage. The benefits were maximized if the scotta was used in the EF and LF growth stages, with rates no less than $300 \mathrm{~g} / \mathrm{kg}$ of fresh forage. 
Author Contributions: Conceptualization, M.M., D.C., and F.F.; methodology, M.M. and F.F.; formal analysis, M.M. and B.T.; investigation, M.M., F.F., B.T., R.G., and V.A.; resources, F.F., B.T., R.G., and V.A.; data curation, M.M, F.F., and B.T.; writing—original draft, F.F., T.B., and F.G.S.A.; writing—review and editing, M.M., F.G.S.A., and D.C.; visualization, M.M. and F.G.S.A.; supervision, M.M.; project administration, M.M. and D.C. All authors have read and agreed to the published version of the manuscript.

Funding: This research received no external funding.

Conflicts of Interest: The authors declare no conflict of interest.

\section{References}

1. McDonald, P. The Biochemistry of Silage; John Wiley and Sons: Chichester, UK, 1981.

2. Jonsson, A. Growth of Clostridium tyrobutiricum during fermentation and aerobic deterioration of grass silage. J. Sci. Food Agric. 1991, 54, 557-568. [CrossRef]

3. Gordon, F.J.; Dawson, L.E.R.; Ferris, C.P.; Steen, R.W.J.; Kilpatrick, D.J. The influence of wilting and forage additive type on the energy utilisation of grass silage by growing cattle. Anim. Feed Sci. Technol. 1999, 79, 15-27. [CrossRef]

4. Orloff, S.; Mueller, S.C. Harvesting, curing and preservation of alfalfa. In Irrigated Alfalfa Management in Mediterranean and Desert Zones; Summers, C.G., Putnam, D.H., Eds.; University of California Agriculture and Natural Resources Publications 8300: Oakland, CA, USA, 2008; Volume 3512, pp. 1-18.

5. Marsh, R. The effects of wilting on fermentation in the silo and on the nutritive value of silage. Grass For. Sci. 1979, 34, 1-10. [CrossRef]

6. Hashemzadeh-Cigari, F.; Khorvash, M.; Ghorbani, G.R.; Taghizadeh, A. The effects of wilting, molasses and inoculants on the fermentation quality and nutritive value of lucerne silage. S. Afr. J. Anim. Sci. 2011, 41, 377-388. [CrossRef]

7. Lloveras, J.; Ferran, J.; Alvarez, A.; Torres, L. Harvest management effects on alfalfa (Medicago sativa L.) production and quality in Mediterranean areas. Grass For. Sci. 1998, 53, 88-92. [CrossRef]

8. Elizalde, J.C.; Merchen, N.R.; Faulkner, D.B. Fractionation of fiber and crude protein in fresh forages during the spring growth. J. Anim. Sci. 1999, 77, 476-484. [CrossRef]

9. Yu, P.; Christensen, D.A.; McKinnon, J.J. In situ rumen degradation kinetics of timothy and alfalfa as affected by cultivar and stage of maturity. Can. J. Anim. Sci. 2004, 84, 255-263. [CrossRef]

10. Yari, M.; Valizadeh, R.; Naserian, A.A.; Ghorbani, G.R.; Moghaddam, P.R.; Jonker, A.; Yu, P. Botanical traits, protein and carbohydrate fractions, ruminal degradability and energy contents of alfalfa hay harvested at three stages of maturity and in the afternoon and morning. Anim. Feed Sci. Tech. 2012, 172, 162-170. [CrossRef]

11. Raguse, C.A.; Smith, D. Some nonstructural carbohydrates in forage legume herbage. J. Agric. Food Chem. 1966, 14, 423-426. [CrossRef]

12. Shao, T.; Ohba, N.; Shimojo, M.; Masuda, Y. Fermentation quality of forage oat (Avena sativa L.) silages treated with pre-fermented juices, sorbic acid, glucose and encapsulated-glucose. J. Fac. Agric. Kyushu Univ. 2003, 47, 341-349.

13. Ohshima, M.; Cao, L.M.; Kimura, E.; Ohshima, Y.; Yokoto, H.O. Influence of addition of previously fermented juice to alfalfa ensiled at different moisture contents. Jpn. J. Grassl. Sci. 1997, 43, 56-58.

14. Wang, J.; Wang, J.Q.; Zhou, H.; Feng, T. Effects of addition of previously fermented juice prepared from alfalfa on fermentation quality and protein degradation of alfalfa silage. Anim. Feed Sci. Technol. 2009, 151, 280-290. [CrossRef]

15. Tyrolová, Y.; Výborná, A. Effect of the stage of maturity on the leaf percentage of lucerne and the effect of additives on silage characteristics. Czech J. Anim. Sci. 2008, 53, 330-335. [CrossRef]

16. Schmidt, R.J.; Hu, W.; Mills, J.A.; Kung, L., Jr. The development of lactic acid bacteria and Lactobacillus buchneri and their effects on the fermentation of alfalfa silage. J. Dairy Sci. 2009, 92, 5005-5010. [CrossRef] [PubMed]

17. Pisponen, A.; Pajumägi, S.; Mootse, H.; Karus, A.; Poikalainen, V. The lactose from Ricotta cheese whey: The effect of $\mathrm{pH}$ and concentration on size and morphology of lactose crystals. Dairy Sci. Technol. 2013, 93, 477-486. [CrossRef] 
18. Kalu, B.A.; Fick, G.W. Quantifying morphological development of alfalfa for studies of herbage quality. Crop Sci. 1981, 21, 267-271. [CrossRef]

19. Darby, D.E.; Jofriet, J.C. Density of silage in horizontal silos. Can. Agric. Eng. 1993, 35, 275-280.

20. Martillotti, F.; Antongiovanni, M.; Rizzi, L.; Santi, E.; Bittante, G. Metodi di Analisi per la Valutazione degli Alimenti D'impiego Zootecnico; Quaderni metodologici n. 8; CNR-IPRA: Roma, Italy, 1987.

21. European Commission. Commission Regulation (EC) No. 152/2009 of 27 January 2009 laying down the methods of sampling and analysis for the official control of feed. Off. J. Eur. Union 2009, L54, 1-130.

22. Canale, A.; Valente, M.E.; Ciotti, A. Determination of volatile carboxylic acids (C1-C5i) and lactic acid in aqueous acid extracts of silage by high performance liquid chromatography. J. Sci. Food Agric. 1984, 35, 1178-1182. [CrossRef]

23. Rohweder, D.; Barnes, R.F.; Jorgensen, N. Proposed hay grading standards based on laboratory analyses for evaluating quality. J. Anim. Sci. 1978, 47, 747-759. [CrossRef]

24. Wall, L.L.; Gehrke, C.W. Automated determination of urea and ammoniacal nitrogen (NPN) in animal feeds. J. Assoc. Off. Anal. Chem. 1981, 64, 1092-1095. [CrossRef] [PubMed]

25. Meteo Pisa. Available online: http://www.meteopisa.net/stazioni/PisaSG.php (accessed on 21 February 2020).

26. Masoni, A.; Mariotti, M.; Arduini, I.; Pampana, S.; Ercoli, L. Nitrate leaching from forage legume crops and residual effect on Italian ryegrass. Agrochimica 2015, 59, 75-91.

27. Yu, P.; Christensen, D.A.; McKinnon, J.J.; Markert, J.D. Effect of variety and maturity stage on chemical composition, carbohydrate and protein subfractions, in vitro rumen degradability and energy values of timothy and alfalfa. Can. J. Anim. Sci. 2003, 83, 279-290. [CrossRef]

28. Canbolat, O.; Kamalak, A.; Ozkan, C.O.; Erol, A.; Sahin, M.; Karakas, E.; Ozkose, E. Prediction of relative feed value of alfalfa hays harvested at different maturity stages using in vitro gas production. Livest. Res. Rural Dev. 2006, 18, 27.

29. Pop, I.M.; Radu-Rusu, C.G.; Simeanu, D.; Albu, A.; Popa, V. Characterization of the nutritional value of alfalfa harvested at different stages of vegetation using cell walls content based methods. Lucrări Ştiinţifice-Seria Zootehnie 2010, 53, 350-354.

30. Karayilanli, E.; Ayhan, V. Investigation of feed value of alfalfa (Medicago sativa L.) harvested at different maturity stages. Legume Res. 2016, 39, 237-247. [CrossRef]

31. Castle, M.E.; Watson, J.N. The relationship between the DM content of herbage for silage making and effluent production. Grass For. Sci. 1973, 28, 135-138. [CrossRef]

32. Repetto, J.L.; Echarri, V.; Aguerre, M.; Cajarville, C. Use of fresh cheese whey as an additive for Lucerne silages: Effects on chemical composition, conservation quality and ruminal degradation of cell walls. Anim. Feed Sci. Technol. 2011, 170, 160-164. [CrossRef]

33. Hartinger, T.; Gresner, N.; Südekum, K.H. Effect of wilting intensity, dry matter content and sugar addition on nitrogen fractions in lucerne silages. Agriculture 2019, 9, 11. [CrossRef]

34. Lancaster, R.J.; Brunswick, L.F.C.; Wilson, R.K. Evaluation of formic acid as an additive for lucerne silage. $N$. Z. J. Exp. Agric. 1977, 5, 107-111. [CrossRef]

35. Weissbach, F. New developments in crop conservation. In Proceedings of the 11th International Silage Conference, Aberystwyth, UK, 8-11 September 1996; Jones, D.H.I., Ed.; IGER: Aberystwyth, UK, 1996; pp. 11-25.

36. Ottaviani, F. L'analisi Microbiologica dei Prodotti Lattiero Caseari, 1st ed.; Tecniche Nuove: Milano, Italy, 1991; pp. 351-374.

37. Dash, S.K.; Voelker, H.H.; Muller, L.D.; Schingoethe, D.J. Comparison between whey and lactose as alfalfa haylage additives. J. Anim. Sci. 1974, 39, 115-123. [CrossRef]

38. Kung, L., Jr.; Shaver, R.D.; Grant, R.J.; Schmidt, R.J. Silage review: Interpretation of chemical, microbial, and organoleptic components of silages. J. Dairy Sci. 2018, 101, 4020-4033. [CrossRef] [PubMed]

39. Truchado, P.; Gil, M.I.; Reboleiro, P.; Rodelas, B.; Allende, A. Impact of solar radiation exposure on phyllosphere bacterial community of red-pigmented baby leaf lettuce. Food Microbiol. 2017, 66, 77-85. [CrossRef] [PubMed]

40. Wieringa, G.W. The effect of wilting on butyric acid fermentation in silage. Neth. J. Agric. Sci. 1958, 6, 204-210.

41. Bastiman, B. Factors affecting silage effluent production. Exp. Husb. 1976, 31, 40-46. 
42. Hashemzadeh-Cigari, F.; Khorvash, M.; Ghorbani, G.R.; Ghasemi, E.; Taghizadeh, A.; Kargar, S.; Yang, W.Z. Interactive effects of molasses by homofermentative and heterofermentative inoculants on fermentation quality, nitrogen fractionation, nutritive value and aerobic stability of wilted alfalfa (Medicago sativa L.) silage. J. Anim. Physiol. Anim. Nutr. 2014, 98, 290-299. [CrossRef]

43. Liu, C.; Lai, Y.J.; Lu, X.N.; Guo, P.T.; Luo, H.L. Effect of lactic acid bacteria inoculants on alfalfa (Medicago sativa L.) silage quality: Assessment of degradation (in situ) and gas production (in vitro). J. Int. Agric. 2016, 15, 2834-2841. [CrossRef]

44. Touqir, N.A.; Khan, M.A.; Sarwar, M.; Nisa, M.; Lee, W.S.; Lee, H.J.; Kim, H.S. Influence of varying dry matter and molasses levels on berseem and lucerne silage characteristics and their in situ digestion kinetics in Nili buffalo bulls. Asian-Aust. J. Anim. Sci. 2007, 20, 887-893. [CrossRef]

(C) 2020 by the authors. Licensee MDPI, Basel, Switzerland. This article is an open access article distributed under the terms and conditions of the Creative Commons Attribution (CC BY) license (http://creativecommons.org/licenses/by/4.0/). 